\title{
Using Means-end Chain Analysis to Reveal Consumers' Motivation for Buying Local Foods: An Exploratory Study
}

\author{
Poppy Arsil, ${ }^{12^{*}}$ Elton Li, ${ }^{1}$ and Johan Bruwer ${ }^{3}$ \\ 1) School of Agriculture Food and Wine, University of Adelaide, Australia \\ ${ }^{2}$ Department of Agricultural Technology, Universitas Jenderal Soedirman, Purwokerto, Indonesia \\ ${ }^{3)}$ School of Marketing, University of South Australia
}

\begin{abstract}
This article utilizes and discusses specific aspects of Means-End Chain (MEC) analysis for understanding the motives of Indonesian consumers when they purchase local food. The MEC theory is used as a measure of the attributes, consequences, and values of locally produced products, involving specific aspects of this theory, namely the laddering methods of administration, the content analysis procedure, and constructing and interpreting a Hierarchy Value Map (HVM). The results of the study indicate that the MEC approach is a powerful method to reveal consumers' motivation for buying local foods, when associated with the various cultural groupings identified by the study, particular between the Javanese and non-Javanese consumers. This study offers a practical implication and source of knowledge for other future studies and policies in terms of: (a) A new approach for understanding the motives behind the purchase of local foods by Indonesian consumers, and (b) developing new categories of attributes, consequences and values for local food.
\end{abstract}

\begin{abstract}
Abstrak: Penelitian ini menggunakan dan membahas berbagai aspek. khusus analisis Means-End Chain (MEC) untuk memahami motif konsumen Indonesia ketika membeli makanan lokal. Teori MEC digunakan untuk mengukur berbagai atribut, konsekuensi dan nilai produk. lokal, termasuk aspek-aspek khusus teori ini yang dikenal dengan metoda adminstrasi berjenjang, prosedur analisis isi, dan Hierarchy Value Map (HVM). Hasil studi mengindikasikan pendekatan MEC adalab metode yang bagus untuk. mengungkapkan bubungan motivasi konsumen dalam membeli makanan lokal berdasarkan kelompok. budaya, terutama antara konsumen Jawa dan non-Jawa. Studi ini dibarapkan dapat memberikan implikasi praktis dan sumber pengetahuan untuk studi mendatang dalam bal penggunaan metode baru untuk memahami motivasi pembelian makan lokal oleh konsumen Indonesia dan pengembangan kategori-kategori baru berbagai atribut, konsekuensi dan nilai makanan lokal.
\end{abstract}

Keywords: consumer motivation; Indonesia; Javanese; local food; means-end chain

JEL classification: M3

* Corresponding author's e-mail: poppy74arsil@gmail.com

ISSN: $1141-1128$ 


\section{Introduction}

The Means End Chain (MEC) theory describes the consumers' knowledge of a product, then relates the attributes of that product, the consequences of its use, and personal values and represents all this in a hierarchical cognitive structure (Gutman 1984). This approach has frequently been applied to understand perceptions about, and why, consumers choose specific food products including beverages, different methods of farming (local and organic foods, and genetically modified products) and different kinds of foods (pork and vegetables) (Gutman 1984; Gengler et al. 1999; Naspetti and Zanoli 2009; Hall and Lockshin 2000; Bredahl 1999; Grunert et al. 2001; Makatouni 2002; Urala and Lähteenmäki 2003; Fotopoulos et al. 2003; Baker et al. 2004; Roininen et al. 2006; Lind 2007; Krystallis et al. 2008; Barrena and Sanchez 2010; Kirchhoff et al. 2011; Arsil et al. 2014b). MECs have also been identified as a useful method to reveal the drivers of consumers' food choices in the United States, many European countries including the United Kingdom, Denmark, Sweden, Belgium, Finland, Greece, Spain, and in Australia (Gutman 1984; Gengler et al. 1995; Bech-Larsen et al. 1996; Fotopoulos et al. 2003; Padel and Foster 2005; Bonne and Verbeke 2006; Roininen et al. 2006; Grantham 2007; Lind 2007; Krystallis et al. 2008; Barrena and Sanchez 2010; Kirchhoff et al. 2011). This method is also used to compare the motivation for food choices between groups of consumers in different countries, and throughout many European countries (Grunert 1997; Bredahl 1999; Valette-Florence et al. 2000; Grunert et al. 2001; Baker et al. 2004; Naspetti and Zanoli 2009).
According to Reynolds and Gutman (1988), a specific product is chosen by consumers because they believe that they could achieve a desired value through the consequences provided by the attributes of the product. MEC theory relates to the attributes (A) and links sequentially to the consequences (C) that derive their importance from the use of the product by satisfying personal values $(\mathrm{V})$, producing an $\mathrm{A}-\mathrm{C}-\mathrm{V}$ sequence and forming a so-called 'ladder.' A Hierarchical Value Map (HVM) is the name given to the graph that is formed from the various 'ladders,' representing the aggregate connections of $A$, $\mathrm{C}$ and V (Reynolds and Gutman 1988). However, some barriers were found that preclude MEC's use, including it being time-consuming, it requires expensive interviews, and artificial sets of answers and researchers' biases that demand a high level of expertise from the interviewers (Veludo-de-Oliveira et al. 2006). MEC theory has previously and exclusively only been applied in developing countries. As a result, there is little discussion about whether the backgrounds and subjects from developing countries affect the usefulness of the MEC's procedure. It is possible that social, personal and cultural backgrounds may seriously influence the outcome of the MEC's approach. Therefore, the first aim of this study is to utilize the MEC's approach to understand the motives behind the purchase of local food by Indonesian consumers.

Many researchers have discussed the details of the MEC theory, examining specific aspects of the theory, including laddering (Grunert and Grunert 1995; Hofstede et al. 1998; Phillips and Reynolds 2009; Reynolds and Gutman 1988; Russell et al. 2004a; Russell et al. 2004b), choosing cut-off levels (Bagozzi and Dabholkar 1994; Pieters et al. 
1995; Reynolds and Gutman 1988), or analyzing, interpreting and presenting the MEC theory (Aurifeille and Valette-Florence 1995; Botschen and Hemetsberger 1998; Gengler et al. 1995; Gutman 1982; Vriens and Hofstede 2000; Leppard et al. 2004; ValetteFIorence and Rapacchi 1991; van Rekom and Wierenga 2007), graphic representations (Gengler et al. 1995), and reviews of the MEC theory (Leppard et al. 2004):

But there is no agreement among researchers as to the way MEC's observations should be analyzed.

The wide application of the MEC theory involves several ways of analyzing, interpreting and presenting the results of laddering data. Therefore, the aim of this paper is to discuss laddering, content analysis, and the interpretation of the HVM that underlies the MEC theory for understanding the motives of Indonesian consumers who purchase local food.

Indonesia, the subject in this study, is an archipelago of many islands and a multiethnic society that consists of approximately 300 ethnic/sub-ethnic groups. The Javanese group is the largest ethnic group in Indonesia and made up 41 percent of Indonesia's population in 2000. They are concentrated on the island of Java, but millions of them have also migrated throughout Indonesia. Moreover, around 60 percent of Indonesian people live on Java, making it the most heavily populated island in the world (Suryadinata et al. 2003). Although Indonesia is the fourth most populous country in the word, it has a great diversity of ethnic groups with different personal, social and economic backgrounds, when compared to most developed countries, but knowledge of Indonesian consumers' behavior toward their local foods is very limited. Therefore, the aim of this study is to apply the MEC approach to understand the motives behind purchasing local foodstuffs between two different groups of consumers: the Javanese and the non-Javanese.

\section{Literature Review}

\section{Laddering Methods of Administration}

Laddering has been named as a technique highlighting a series of guidelines to be followed during the primary data collection through interviews in the context of the MEC theory (Phillips and Reynolds 2009; Reynolds and Gutman 1988). Reynold and Gutman (1988, p.12) stated Laddering refers to an in-depth, one-on-one interview technique used to develop an understanding of how consumers translate the attributes of products into meaningful associations with respect to themselves, following the meansend theory.

This method of laddering has been applied to operationalize the MEC theory with respect to its capability to elicit hierarchical constructs of $\mathrm{A}-\mathrm{V}-\mathrm{C}$ in sequential form (Phillips and Reynolds 2009; Reynolds and Gutman 1988). Philip and Reynolds (2009, p.85-86) have argued that some fundamental assumptions are required to obtain hierarchical networks of meaning from ladders generated from respondents' interviews. Firstly, ladders are generated from preferences and meaningful choices. Then, respondents need to think deeply prior to responding by asking "Why is that important to you?" questions. After that, complete ladders can be achieved from the collection of the respondents' responses consisting of Attributes (A), Consequences $(\mathrm{C})$ and Values $(\mathrm{V})$. There is a need to make sure that interviewers obtain the $A$ 
Table 1. The Advantages and Challenges of the Soft and Hard Laddering Methods of Administration Linked to the MEC Theory

\section{Type of Laddering Advantages and Challenges}

\section{Soft Laddering}

(based on pen and paper)

\section{Hard laddering}

(based on computer or paper-and pencil)

\section{Advantages}

More linkages were produced between the levels of abstraction (Russell et al. 2004a, p. 545). Would uncover a complex pictorial representation of how consumers perceived and linked the A-C-V (Russell et al. 2004a). Produced higher frequency of attributes and consequences (Botschen and Hemetsberger 1998)

\section{Challenges}

Requires highly skilled and expert interviewers, time consuming, expensive interviews (Hofstede et al. 1988; Veludo-de-Oliveira 2006), artificial sets of answers, simplistic analysis of the results (Veludo-de-Oliveira 2006) and researchers' bias (Veludo-de-Oliveira 2006, Botsschen et al. 1999)

\section{Advantages}

Produced more ladders (Grunert and Grunert 1995), efficiency in data collection (quicker and cheaper) (Grunert and Grunert 1995; Botsschen et al. 1999), suitable for investigating the strong links within the linkages (Russell et al. 2004b), and minimize researchers' influence (Grunert and Grunert 1995; Veludo-de-Oliveira 2006)

\section{Challenges}

The consistency of the codings' interpretation among the respondents was questionable. There is a possible effect of bias for the abstract concepts and cross-cultural applications. There is the potential of missing levels of abstraction since only the specific coding is provided to the respondent to be selected. Since laddering is a recall recognition task, this technique might result in fatigue and boredom (Reynolds 2006).
$\mathrm{C}, \mathrm{V}$ in a given ladder, and that no levels of abstraction are out of sequence or missed. The last assumption was that an appropriate concept code should be developed that would accurately reflect the level of meaning involved.

There have been two laddering methods of administration that have commonly been used by researchers in several MEC studies published in scholarly journals, namely the 'soft' and 'hard' laddering ap- proaches (Grunert and Grunert 1995). 'Soft' laddering is the original and common method of administration, which employs individual face-to-face and semi-structured interviews (Leppard et al. 2004). Consumers are prompted to produce a 'ladder' by using a specific question, such as, "Why is the attribute important for you?" By this method, it is hoped that respondents would reveal the connections between the attributes that the products have, with respect to the conse- 
quences of the product's use, and end in the values. When written questionnaires are used to obtain information from respondents, it is called 'hard' laddering. The information obtained could be based on pencil-and-paper or computerised questionnaires, and is an alternative method for uncovering the level of abstraction in the context of the MEC's approach (Reynolds and Gutman 1988; Russell et al. 2004b). The advantages and challenges of the 'hard' and 'soft' laddering methods of administration are shown in Table 1 . The application of the laddering method of administration has varied between researchers. Philip and Reynolds (2009, p.85) stated.

This is a particular concern because, as with pre-coded and open-ended survey questions, it is possible that 'hard' and 'soft' laddering approaches will yield different results, and researchers using different approaches may not draw the same conclusions when investigating a similar research question.

The complexity, as well as the level of involvement with the product, are important factors to be considered when choosing the method of administration with respect to laddering (Grunert and Grunert 1995; Russell et al. 2004b). In this study, a routine and habitual activity, namely 'the motives of Indonesian consumers to purchase local food,' is selected since this research study emphasizes the application of the MEC theory with respect to consumers from a developing country's background. Food purchasing is a habitual and routine activity, but with the increasing encroachment of processed foods through mass retailers such as supermarkets, the attributes of locally grown products are sufficient to explore.

\section{Content Analysis}

Content analysis has been argued to be a scientific analysis that systematically evaluates all forms of communication messages (Kolbe and Burnett 1991). A guide to the methodological benchmarks for research into consumers' behavior is offered by Kassarjian (1977). According to Reynolds and Gutman (1988), the first step in content analysis is to code the recording of the complete interview with the respondents and then to develop a set of master codes that represent the levels of hierarchy. Subsequently, an individual summary code for each respondent can be developed. Very broad coding in the content analysis procedure means that too much meaning can be lost. Re-reading and extensive discussions is one way of dealing with this problem.

Boschen et al. (1999) published an overview of the levels of hierarchies. The concrete attributes are the tangible attributes, such as color and weight. They could be measured physically. The abstract attributes are defined as intangible characteristics such as 'smell nice' or 'pleasant feeling.' They are subjective but can be measured. According to Gutman (1982, p.61), consequences refer to "Any results (physiological or psychological accruing directly or indirectly to the consumer (sooner or later) from his or her behavior" The functional consequences are the tangible outcomes of using a product, while the psychosocial consequences are psychosocial and social outcomes arising from the use of a specific product. The level of satisfaction as a consequence influences personal values. There are two types of values: 'Instrumental' values and 'terminal' values. The 'instrumental' values reflect modes of conduct to achieve the 'terminal' values, as perceived by others (Reynolds and Gutman 1988). The end goal for the consumer is 'terminal' values that 
are related to the personal views of the consumers (Prescott et al. 2002). This concept provides an understanding of the actions and behavior of consumers. In the means-end chain, the 'terminal' value has a dominant role in the consumers' motivation for their purchasing decisions (Vriens and Hofstede 2000). The personal values emerge if consumers are able to link the attributes that the products have with positive consequences, and lead to the attainment of the desired values. The stronger the A-C-V link is, as identified by the consumers, means that they are highly involved and comply with a meansend association (Gengler et al. 1995).

\section{Generating a Hierarchy Value Map (HVM)}

HVM has been the popular approach for analyzing laddering data (Reynolds and Gutman 1988). Once all the individual matrixes have been finalized, the numbers of direct and indirect relationship are assigned to a summary implication matrix. The implication matrix displays the number of occasions on which each element in a given row leads to each other element in a square matrix, usually between 30 to 50 codes (Reynolds and Gutman 1988). The direct relationships are 'implicative relationships among adjacent elements' (Reynolds and Gutman 1988, p.20), whereas the indirect relationships are 'the connections among elements when there is another element between them' (Veludo-de-Oliveira et al. 2006, p. 634).

The output of a MEC study is a treelike network diagram called a HVM, which is a graphical representation of the aggregate map of cognitive structures (Reynolds and Gutman 1988). The hierarchical value map, formed from an aggregate matrix, is constructed by connecting the chain and considering the number of linkages among the elements.

To construct a HVM requires the choice of the cut-off level. Reynold (2006, p.450) stated that:

This required choice of the cut-off level for this deterministic type of analysis is obviously quite problematic in the sense that the exact same set of laddering data can result in different HVM representations, depending upon the research analyst's decision.

Reynold and Gutman (1988) suggest a cut off level of between 3 to 5 relations, typically involving a cut of 4 relations from 50 respondents, and 125 ladders which would represent two thirds of the relationships among the elements. The type of relationship that mostly commonly represents the standard basis on which to construct the hierarchy is typically A-D, which is mapped as being adjacent with a high number of direct relationships.

\section{Interpretation of $H V M$}

A network analysis approach could be used for analyzing MEC data as this approach can identify which elements are the means or the ends, by using an abstractness ratio and then calculate the centrality index to represent the degree of the central role for each element in the HVM (see Pieters et al. 1995 for detail calculation). On the basis of these two indexes, the main pathways for consumers' motivation to buy local food can be identified. 


\section{Methods}

\section{Sampling}

Indonesia consists of hundreds of ethnic groups. The Javanese form the largest ethnic group and comprise more than 40 percent of Indonesia's population. Our participants were 52 Indonesian consumers who consisted of Javanese and non-Javanese consumers of local foodstuffs who were living in Adelaide. This study is part of a comprehensive Ph.D. research. As this study's focus is on the application of the MEC theory, in the form of a pilot study, the respondents were chosen because they were close to the researcher's place. The findings of this study, in terms of the way the MEC data should be

Table 2. Demographic Characteristics of Survey Respondents

\begin{tabular}{|c|c|c|c|c|c|}
\hline \multirow[t]{2}{*}{ Characteristics } & \multicolumn{2}{|c|}{ Personal } & \multicolumn{3}{|l|}{ Home and Status } \\
\hline & $\mathbf{N}$ & $\%$ & Characteristics & $\mathbf{N}$ & $\%$ \\
\hline \multicolumn{3}{|l|}{ Consumers' ethnicity } & \multicolumn{3}{|l|}{ Visa types held } \\
\hline Javanese consumers & 31 & 59.6 & Student & 30 & 57.8 \\
\hline Non-Javanese consumers & & & Permanent resident & 9 & 17.3 \\
\hline From Sumatra Island & 13 & 25.1 & Visitors & 5 & 9.6 \\
\hline From Kalimantan Island & 4 & 7.7 & Temporary business & 5 & 9.6 \\
\hline From Sulawesi Island & 1 & 1.9 & Visiting academic & 2 & 3.8 \\
\hline From Maluku/Nusa Tenggara & 3 & 5.7 & Special program & 1 & 1.9 \\
\hline \multicolumn{3}{|l|}{ Gender } & \multicolumn{3}{|l|}{ Marital status } \\
\hline Male & 19 & 36.5 & Single & 5 & 9.6 \\
\hline \multirow[t]{2}{*}{ Female } & 33 & 63.5 & Married & 46 & 88.5 \\
\hline & & & Widow or Divorced & 1 & 1.9 \\
\hline Age (years old) & & & \multicolumn{3}{|c|}{ Living in Adelaide (years) } \\
\hline$\leq 30$ & 11 & 21.1 & $\leq 5$ & 44 & 84.6 \\
\hline $30 \leq 40$ & 20 & 38.5 & $5 \leq 10$ & 3 & 5.6 \\
\hline $40 \leq 50$ & 13 & 25.0 & $10 \leq 15$ & 1 & 1.9 \\
\hline $50 \leq 60$ & 7 & 13.5 & $15 \leq 20$ & 1 & 1.9 \\
\hline \multirow[t]{4}{*}{$60 \leq 70$} & 1 & 1.9 & $20 \leq 25$ & 2 & 3.8 \\
\hline & & & $25 \leq 30$ & 0 & 0 \\
\hline & & & $30 \leq 35$ & 0 & 0 \\
\hline & & & $35 \leq 40$ & 1 & 1.9 \\
\hline Educational level attained & & & \multicolumn{3}{|c|}{ Family income(AUD/month) } \\
\hline High School & 3 & 5.8 & $\leq 2000$ & 7 & 13.5 \\
\hline Undergraduate & 19 & 36.5 & $2000<$ and $\leq 4000$ & 28 & 53.8 \\
\hline \multicolumn{6}{|l|}{ Masters degree and } \\
\hline professional program & 20 & 38.4 & $4000<$ and $\leq 6000$ & 11 & 21.2 \\
\hline Doctorate & 7 & 13.5 & $6000<$ and $\leq 8000$ & 3 & 5.8 \\
\hline Post Doctorate & 2 & 3.8 & $8000<$ and $\leq 10000$ & 2 & 3.8 \\
\hline Professor & 1 & 1.9 & $10000<$ and $\leq 12000$ & 1 & 1.9 \\
\hline
\end{tabular}


analyzed and interpreted, as well as the categories of the attributes, consequences and values will all be valuable inputs to a bigger survey in Indonesia of Indonesian consumers of local food. The snowball technique was chosen to select respondents for practical reasons. They were selected based on two critical characteristics, namely: (a) Food making deciders (the definition of 'food decider' refers to Schiffman and Kanuk 2010, p. 353) and (b) they were above 17 years old. These two characteristics are used to ensure that the respondents understood the topic that the interviewers addressed during the scheduled interviews. The meaning of 'local' as used in this study refers to Arsil et al. (2014a). The respondents were heterogeneous with respect to their ethnic groups, gender, age, marital status, educational level, visa type held, and how long they had been living in Adelaide, as shown in Table 2. Most of the respondents were female, of a mature age, with a high level of education, had lived for less than 5 years in Adelaide and had a family income of between 2,000 to 4,000 AUD per month. The interviews ranged in time from 45 minutes to 2 hours, and were held in a place selected by the respondents (at their home, in their office, at a cafe, or in the mall) during October and November 2010. A souvenir costing 5 AUD was provided for each respondent, to thank them for their contribution to this study. A response rate of 93 percent was achieved.

\section{MEC Procedures Employed}

'Soft' laddering was chosen for use in this study, with a triadic sorting technique. The respondents were provided with a picture of three sets of food products: Local, national and imported. Distinctions were elicited from the individual respondents based on meaningful differences between the sets of food products. Then laddering was gener- ated by asking the question "Why is this element important for you?" All the interviews were recorded and transcribed. A series of codes for the attributes to the highest level of values was constructed using content analysis procedures (Kassarjian 1977; Reynolds and Gutman 1988). An implication matrix of all the pair-wise connections was obtained by using a cut-off level of four to allow only the most frequently chosen links to be included in the HVM, and then the HVM was created. The HVM was formed by the various ladders which represent the relationships of all the attributes, consequences, and values related to the products. To determine the perceptual presentations, the intrachain relationships would be summarized and evaluated (Gutman and Reynold (1988, page 23-25 for details). In this study, a network analysis approach was chosen for analyzing and presenting the MEC's data.

\section{Results and Discussion}

\section{Laddering Method of Administration}

Russell et al. (2004b, p. 573) defined a ladder as "One's participant sequence of responses from attributes to a higher level of abstraction." Ladders can then be constructed using several individual ladders to form a chain (Reynolds and Gutman, 1988). Laddering is commonly used to produce ladders.

Although several research studies of local food have revealed meaningful choices, the underlying attributes, consequences and values, with respect to the MEC theory [for example: Lind (2007) and Roininen et al. (2006)], differ considerably for Indonesian consumers, as they involve personally and socially different views and beliefs. Thus 'soft' 
laddering is employed in this study, since this method offers considerable consumer involvement and cognitive effort, in order to recall personally meaningful abstractions of the consumers. 'Soft' laddering is also an appropriate approach for a study that has little knowledge of the attributes, consequences and values.

\section{Content Analysis}

Interview transcripts are coded with an open coding procedure. The results of the content's analysis using idiosyncratic concepts and a coding schedule produced 15 attributes, 17 consequences and 8 values terms (Table 3). Grunert and Grunert (1995) have argued that some of the bias in content analysis could arise from interference by the researcher during the coding process. The pro- cedure of defining the elements, and selecting and grouping the variables could also be a source of bias as it is a subjective process (Lin 2002). In this case, involvement in previous studies can be of advantage during the content analysis's process. The previous studies reviewed in this investigation were restricted to articles about food choices using the MEC theory, which did help the researcher to identify coding themes from the raw data. The categories of the attributes, consequences and values have been summarized in Table 3.

\section{Discussion: Hierarchy Value Maps (HVMs) of Local Food}

This study highlights that the network analysis approach, using the concepts of the

Table 3. The Attributes, Consequences, and Values Coding of Local Foods

\begin{tabular}{|c|c|c|}
\hline Attributes & Consequences & Values \\
\hline - Inexpensive & - Good health & - Fun and enjoyment in life \\
\hline - Freshness & - Earn money & - Self-respect \\
\hline - Healthy food & - Save money & - Security \\
\hline - Good taste & - Controlling budget & - Sense of accomplishment \\
\hline - Enjoyable food & - Save time and energy & - Better family relationship \\
\hline - Easy preparation and cooking & - Time for other things & - Thank God \\
\hline - Familiar products & - Money for other things & - Life satisfaction \\
\hline - Trust the food & - Green generation & - Health is the most important thing in life \\
\hline - Options & - Local economic growth & \\
\hline - Offering for a special occasion & - Prosperous nation & \\
\hline - Locally grown & - Environmentalquality & \\
\hline - Patriotism & - Good value food & \\
\hline - Maintain local resources & - Can afford & \\
\hline - Support local communities & - Practical implications of the food & \\
\hline \multirow[t]{3}{*}{ - Bring back memories } & - Socialinteraction & \\
\hline & - Social equity and security & \\
\hline & - Self-esteem & \\
\hline
\end{tabular}


Arsiletal.

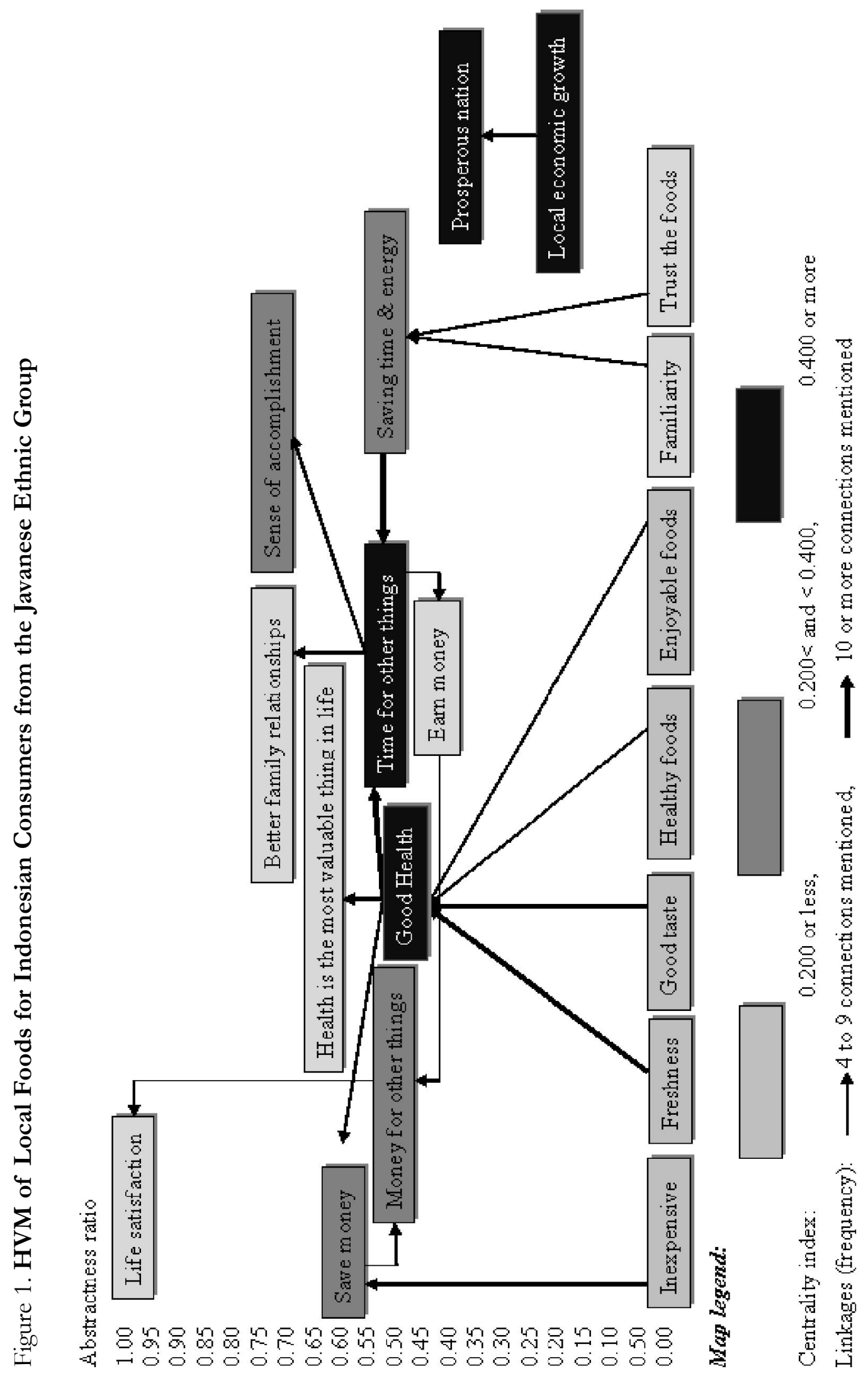




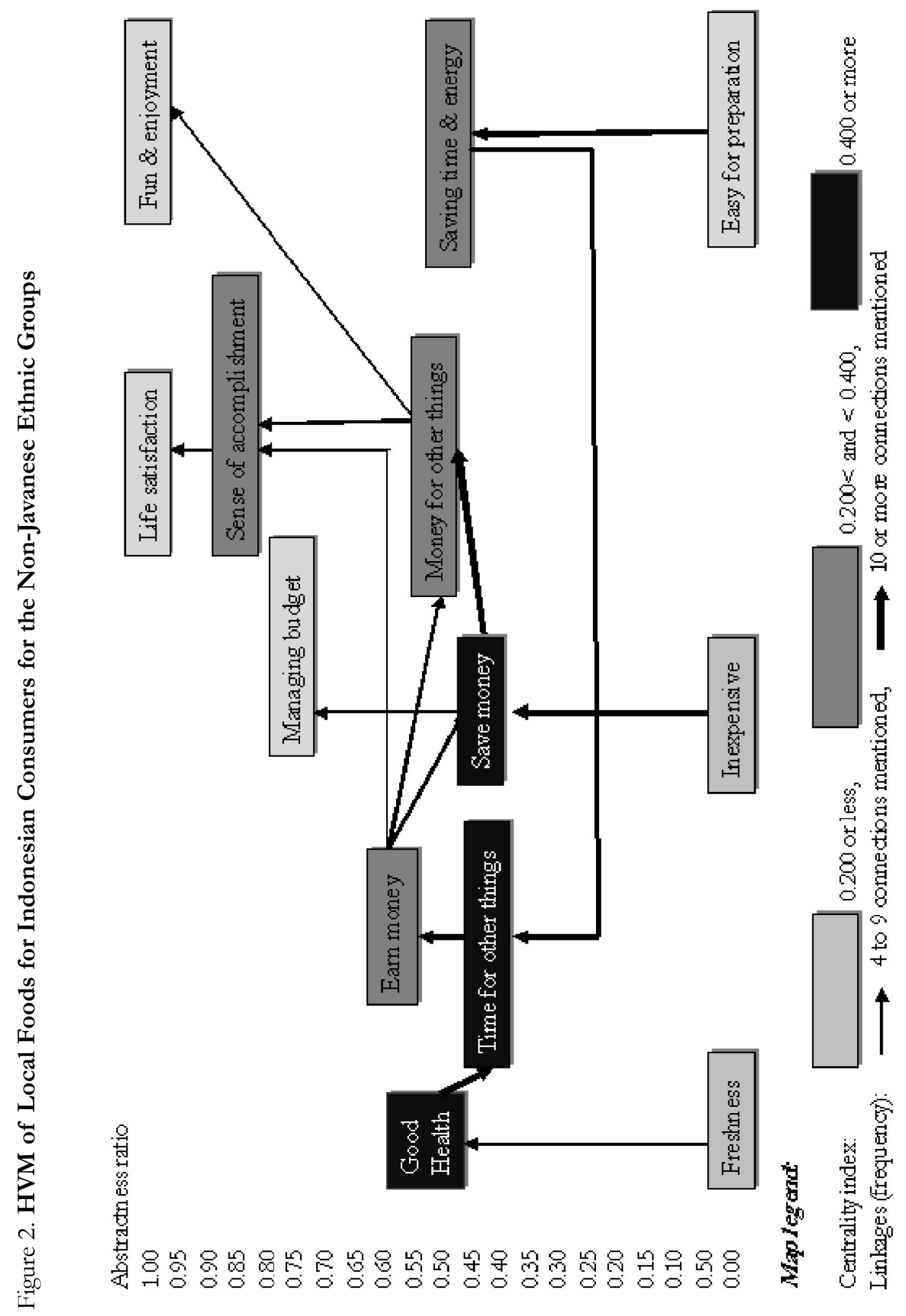


abstractness ratio and centrality index, provides a powerful method for revealing what motives drive Indonesian consumers to purchase their local foodstuffs. The consumers' main goals are presented in the HVMs, which yield a quick and better understanding of why consumers buy local food. Figure 1 shows the HVM of local food for Javanese consumers and Figure 2 presents the HVM of local food for non-Javanese consumers.

The findings show that the HVMs for local food differ between the Javanese and non-Javanese consumers and are summarized below:

- The HVM of local food for Javanese consumers is richer in attributes and values than the HVM of local food for the nonJavanese consumers. For Javanese consumers, two separate ladders are produced from the laddering interviews that result in 8 attributes, 7 consequences and 4 values. In contrast, only 3 attributes, 7 consequences and 3 values are involved in one HVM of the local food for non-Javanese consumers.

- In terms of the context of centrality, good health is the greatest importance of cognition (0.613) for the Javanese consumers, followed by time for other things (0.484), a sense of accomplishment (0.323) and a prosperous family/area/nation (0.306). In contrast, time for other things (0.526), managing a budget (0.516), good health (0.400), money for other things (0.386), earning money (0.379) and saving time and energy (0.316) are the central elements for the non-Javanese consumers. Those elements play an important role in the decision making process for local food.

- Values that can be inserted for an advertising strategy for the Javanese consumers are 'sense of accomplishment', 'life satis- faction', 'better family relationship' and 'health is the most valuable thing in life,' whereas for non-Javanese consumers, the important values are 'sense of accomplishment', 'life satisfaction' and 'fun and enjoyment in life.'

- Three main pathways are found from the HVM for Javanese consumers, based on the linkages within the HWM.

- The firstpathway is named "Trust the food so you feel a sense of accomplishment." This pathway is: Trust the food $\rightarrow$ save time and energy $\rightarrow$ time for other things $\rightarrow$ sense of accomplishment.

- The second pathway is named "Good health" and the pathway is: Freshness $\rightarrow$ good health $\rightarrow$ time for other things $\rightarrow$ sense of accomplishment.

- The third chain is called "Support our local communities for a prosperous nation." The linkage is: Support local communities $\rightarrow$ prosperous nation.

- There are 2 dominant pathways within the HVM for non-Javanese consumers.

- The first main chain is named "Easy to prepare so you have fun and enjoyment," which is the pathway: Easy to prepare $\rightarrow$ save time and energy $\rightarrow$ time for other things $\rightarrow$ earn money $\rightarrow$ save money $\rightarrow$ money for other things $\rightarrow$ fun and enjoyment.

- The second linkage is called "Inexpensive price will create fun and enjoyment." The linkage is: Inexpensive $\rightarrow$ save money $\rightarrow$ money for other thing $\rightarrow$ fun and enjoyment.

- The HVM's interpretation is highly suited for Javanese consumers in many categories including age, education level, visa type held and family income, while for nonJavanese consumers the HVM's interpretation is highly suited for people who have 
lower-medium family incomes, are underforty years of age and hold a student or permanent resident visa.

Philip and Reynold (2009) state that one of the laddering assumption that might be met is that participants' responses result in a complete ladder that consists of three levels of abstraction $(\mathrm{A}, \mathrm{C}, \mathrm{V})$. However, in this study the higher values are not always achieved for all the HVMs, particularly in the HVM for the non-Javanese consumers, so this assumption was not met. In contrast, the findings of this study do not imply a failure to meet the laddering assumptions, as consumers may have incomplete ladders due to their lack of product experience or the present of a few simple products (Olson and Reynolds 2003). Costa et al. (2004) argue that food choice is a habitual and routine activity that results in HVMs that are rich in attributes and consequences. In this case the HVMs of consumers from the island of Java are likely to be richer in attributes and values.

\section{Conclusion}

Although Means-End Chains (MEC) are frequently used for understanding the motivation behind particular food choices, little is known about the application of the MEC approach among subjects from a developing country. The MEC theory provides a quick and better approach for understanding the motivation behind food choices. A discussion of the MEC process is provided that includes some consideration of the specific approach selected. Thus, this study offers a seminal understanding of the motives for the choice of local food.

The contribution of this study also provide a better perspective of the local food- stuffs among Indonesian consumers, and develops new categories of attributes, consequences and values that are from a combination of our field results and the large number of previous studies using the MEC process in the context of food choices.

Therefore, the result of this study can be used for a survey that involves a larger population, in particularly Indonesia and Asian countries in general. The motives behind purchasing local food for Javanese people: 'Trust the food', 'good health' and 'support the local community' are highlighted views that motivate consumers to buy local fresh produce while for non-Javanese people, 'easy for preparation' and 'inexpensive price' are important views that motivate them to purchase local food.

However, this study has two limitations. Firstly, a potential bias may come from the content analysis procedure we employed. Multiple coders were not used in this study during the development of the list of the categories of the attributes, consequences and values. Multiple coders can provide a better level of methodological rigor and avoid a potential bias source arising from the researchers who extract the themes from the interview transcripts. Secondly, the subjects in this study are limited to Indonesian consumers who live or stay in Adelaide. These respondents seem to have a higher level of education and a higher family income when compared to consumers who live in Indonesia.

The results of this study cannot be generalized to all Indonesian consumers, as this study investigating Indonesian consumers living in Adelaide and a larger sample needs to be studied to generalize the results to the wider population in Indonesia. 


\section{Acknowledgement}

We would like to express our sincere gratitude to Prof. Tony Spawton and Prof. John Keeves for their valuable feedback to improve the quality of this paper. We also would like to thank the two anonymous reviewers for their helpful and insightful comments and suggestions.

\section{References}

Arsil, P., E. Li, and J. Bruwer. 2014a. Perspectives on Consumer Perceptions of Local Foods: A View from Indonesia. Journal of International Food \& Agribusiness Marketing 26 (2):107-124.

Arsil, P., E. Li, J. Bruwer, and G. Lyons. 2014b. Exploring consumer motivations towards buying local fresh food products: A means-end chain approach. British Food Journal 116 (10): 1533 - 1549.

Aurifeille, J-M., and P. Valette-Florence. 1995. Determination of the dominant means-end chains: A constrained clustering approach. International Journal of Research in Marketing 12 (3): 267-278.

Bagozzi, R. P., and P. A. Dabholkar. 1994. Consumer recycling goals and their effect on decisions to recycle: A means-end chain analysis. Psychology and Marketing 11 (4): 313-341.

Baker, S., K. E. Thompson, J. Engelken, and K. Huntley. 2004. Mapping the values driving organic food choices: Germany vs the UK. European Journal of Marketing 38 (8): 995-1012.

Barrena, R., and M. Sanchez. 2010. Frequency of consumption and changing determinants of purchase decisions: From attributes to values in the organic food market. Spanish Journal of Agricultural Research 8 (2): 251-272.

Bech-Larsen, T., N. A. Nielsen, K. G. Grunert, and E. Sorensen. 1996. Means-end chains for low involment food products - a study of Danish consumers' cognitions regarding different applications of vegetable oil. Working paper. The Aarhus School of Business.

Bonne, K., and W. Verbeke. 2006. Muslim consumer's motivations towards meat consumption in Belgium: Qualitative exploratory insights from means-end chain analysis. Anthropology of Food 5: 1-24.

Botschen, G,. and A. Hemetsberger. 1998. Diagnosing Means-End Structures to Determine the Degree of Potential Marketing Program Standardization. Journal of Business Research 42 (2): 151-159.

Botschen, G., E. M. Thelen, and R. Pieters. 1999. Using means-end structures to benefit segmentation an application for services. European Journal of Marketing 33 (1-2): 38-58.

Bredahl, L. 1999. Consumers cognitions with regard to genetically modified foods. Results of a qualitative study in four countries. Appetite 33 (3): 343-360.

Costa, A. I. A., M. Dekker, and W. M. F. Jongen. 2004. An overview of the means-end theory: Potential applications in consumer-oriented food products design. Trends in Food Science \& Technology 15 (78): 403-415.

Fotopoulos, C., A. Krystallis, and M. Ness. 2003. Wine produced by organic grapes in Greece: Using means-end chains analysis to reveal organic buyers' purchasing motives in comparison to the nonbuyers. Food Quality and Preference 14 (7): 549-566.

Gengler, C. E., D. B. Klenosky. and M. S. Mulvey. 1995. Improving the graphic representation of meansend results. International Journal of Research in Marketing 12 (3): 245-256.

Gengler, C. E., M. S. Mulvey, and J. E. Oglethorpe. 1999. Means-End Analysis of mothers' infant feeding choices. Journal of Public Policy and Marketing 18 (2): 172-188. 
Grantham, S.. 2007. But what do they really think? Identifying consumers' values relevant to adopting biotechnologically produced foods. Journal of Public Affairs 7 (4): 372-382.

Grunert, K. G. 1997. What's in a steak? A cross-cultural study on the quality perception of beef. Food Quality and Preference 8 (3): 157-174.

Grunert, K. G., and S. C. Grunert. 1995. Measuring subjective meaning structures by the laddering method: Theoretical considerations and methodological problems. International Journal of Research in Marketing 12 (3): 209-225.

Grunert, K. G., L., Lähteenmäki, N. A. Nielsen, J. B. Poulsen, O. Ueland, and A. Åström. 2001. Consumer perceptions of food products involving genetic modification-results from a qualitative study in four Nordic countries. Food Quality and Preference 12 (8): 527-542.

Gutman, J. 1982. A means-and chain model based on consumer categorization processes. The Journal of Marketing 46 (2): 60-72.

Gutman, J. 1984. Analysing consumer orientations toward beverages through means-end chain analysis. Psychology and Marketing 1 (3/4): 23-43.

Hall, J. and L. Lockshin. 2000. Using means-end chains for analysing occasions - not buyers. Australasian Marketing Journal (AMJ) 8 (1): 45-54.

Hofstede, F.t., A. Audenaert, J. B. E. M. Steenkamp, and M. Wedel. 1998. An investigation into the association pattern technique as a quantitative approach to measuring means-end chains. International Journal of Research in Marketing 15 (1): 37-50.

Kaciak, E., and C. W. Cullen. 2006. Analysis of means-end chain data in marketing research. Journal of Targeting, Measurement and Analysis for Marketing 15 (1): 12-20.

Kassarjian, H. H. 1977. Content analysis in consumer research. Journal of Consumer Research 4 (1): 8-18.

Kirchhoff, S., H.Smyth, J. Sanderson, Y. Sultanbawa, and K. Gething, 2011. Increasing the consumption of vegetables: A means-end chain approach. British Food Journal 113 (8): 1031-1044.

Kolbe, R. H., and M. S. Burnett. 1991. Content-analysis research: An examination of applications with directives for improving research reliability and objectivity. Journal of Consumer Research 18: 243-250.

Krystallis, A., G. Maglaras, and S. Mamalis. 2008. Motivations and cognitive structures of consumers in their purchasing of functional foods. Food Quality and Preference 19 (6): 525-538.

Leppard, P., C. G. Russell, and D. N. Cox. 2004. Improving means-end-chain studies by using a ranking method to construct hierarchical value maps. Food Quality and Preference 15 (5): 489-497.

Lin, C. 2002. Attribute-consequence-value linkages: A new technique for understanding customers' product knowlegde. Journal of Targeting, Measurement and Analysis for Marketing 10: 339-352.

Lind, L. W. 2007. Consumer involvement and perceived differentiation of different kinds of pork - a means-end chain analysis. Food Quality and Preference 18 (4): 690-700.

Makatouni, A. 2002. What motivates consumers to buy organic food in the UK? Results from a qualitative study. British Food Journal 104 (3/4/5): 345-352.

Naspetti, S, and R. Zanoli. 2009. Organic food quality and safety perception throughout Europe. Journal of Food Products Marketing 159 (3): 249-266.

Olson, J. C. and T. J. Reynolds. 2003. 'Understanding consumers' cognitive structures: Implication for advertising strategy'. In Percy, L. and Woodside, A. (eds), Advertising and Consumer Psychology: 77-91. Lexington, MA, Lexinton Books. 
Padel, S., and C. Foster. 2005. Exploring the gap between attitudes and behaviour: Understanding why consumers buy or do not buy organic food. British Food Journal 107 (8): 606-625.

Phillips, J. M., and T. J. Reynolds. 2009. A hard look at hard laddering: A comparison of studies examining the hierarchical structure of means-end theory. Qualitative Market Research: An International Journal 12(1): 83-99.

Pieters, R., H. Baumgartner, and D. Allen. 1995. A means-end chain approach to consumer goal structures. International Journal of Research in Marketing 12 (3): 227-244.

Prescott, J., O. Young, L. O’Neill, N. J. N. Yau, and R. Stevens. 2002. Motives for food choices: A comparison of consumers from Japan, Taiwan, Malaysia and New Zealand. Food Quality and Preference 13 (7-8): 489-495.

Reynolds, T. J. 2006. Methodological and strategy development implications of decision segmentation. Journal of Advertising Research 46 (4): 445-461.

Reynolds, T. J. and J. Gutman. 1988. Laddering theory, method, analysis, and interpretation. Journal of Advertising Research 28 (1): 11-31.

Roininen, K., A. Arvola, and L. Lähteenmäki. 2006. Exploring consumers' perceptions of local food with two different qualitative techniques: Laddering and word association. Food Quality and Preference 17 (1-2): 20-30.

Russell, C. G., A. Busson, I. Flight, J. Brian, J. A.v.L. van Pabst, and D.N. Cox. 2004a. A comparison of three laddering techniques applied to an example of a complex food choice. Food Quality and Preference 15: 569-583.

Russell, C. G., I. Flight, P. Leppard, J. A.v.L. van Pabst, J. A. Syrette, and D.N. Cox. 2004b. A comparison of paper-and-pencil and computerised methods of 'hard' laddering. Food Quality and Preference 15 (3): 279-291.

Schiffman, L. G, and L. L. Kanuk. 2010. Consumer Behaviour (6th ed.). New Jersey: Prentice Hall.

Suryadinata, L., E. N. Arifin, and A. Ananta. 2003. Indonesia's Population: Ethnicity and Religion in a Changing Political Landscape. Singapore: Institute of Southeast Asian Studies.

Urala, N., and L. Lähteenmäki. 2003. Reasons behind consumers' functional food choice. Nutrition and Food Science 33 (4): 148-158.

Valette-FIorence, P., and B. Rapacchi. 1991. Improving means-end chain analysis using graph theory and correspondence analysis. Journal of Advertising Research 31 (1): 30-45.

Valette-Florence, P., L. Sirieix., K. Grunert, and N. Nielsen. 2000. Means-end chain analyses of fish consumption in Denmark and France: A multidimensional perspective. Journal of Euromarketing 8 (1-2): 15-27.

van Rekom, J., and B. Wierenga. 2007. On the hierarchical nature of means-end relationships in laddering data. Journal of Business Research 60 (4): 401-410.

Veludo-de-Oliveira, T. M., A. A. Ikeda, and M. C. Campomar. 2006. Laddering in the practice of marketing research: Barriers and solutions. Qualitative Market Research: An International Journal9 (3): 297306.

Vriens, M., and F. T. Hofstede. 2000. Linking attributes, benefits, and consumer values. Journal of Marketing Research 12 (3): 4-10. 